\title{
Correction of the Field in the SSC Dipoles Using Superconductor on the Wedges
}

\author{
M.A. Green \\ Lawrence Berkeley Laboratory, University of California, \\ Berkeley, CA 94720
}

\author{
R.M. Talman \\ Cornell University, Ithaca, NY 14853
}

\section{DISCLAIMER}

\begin{abstract}
This report was prepared as an account of work sponsornd by an agency of the United States Government. Neither the United States Government nor any agency thereof, nor any of their employoes, mukes ary warranty, express or implied, or assumes any leyal liability or responsibility for the accuracy, completeness, er usefulness of any information, apparatus, product, or process disclosed, or represents that its use would not infringe privately ownod rights. Reference herein to any specific commercial product, process, or service by trade name, trademark, manufucturer, or otherwise does not necessarily constitute or imply its endorsement, recommendation, or favoring by the United States Government or any agency thereof. The views and opinions of authors expressed berein do not necessarily state or reflect those of the Unitod States Goverament or any agency thereol.
\end{abstract}




\title{
Correction of the Field in the SSC Dipoles Using Superconductor on the Wedges
}

\author{
M.A. Green \\ Lawrence Berkeley Laboratory, University of California, \\ Berkeley, CA 94720
}

R.M. Talman

Cornell University, Ithaca, NY 14853 


\author{
M. A. Green \\ Laurence Berkeley Laboratory, Berkeley, CA 74720 \\ R. H. Taloan \\ Coraell University, Ithaca, NY 24853
}

\section{ABSTRACT}

The SSC colliting bean scorage ring requirea auperconducting argnets capable of produclins a acnetic cield of $6.6 \mathrm{~T}$ which has rery higb accuracy. For any of the multipolea, that molipole must be reduced (at a radiua of 1 centibeter) to the order of 0.2 parts in 10,000. Thls fleld eccuracy 1e dictated by the phynics of storing very sandl bigh-eurrent proton bean at energles rangins froa $1 \mathrm{TeV}$ to $20 \mathrm{IeV}$. Magnetization of the superconduczor can cauae sextupole flelu errots of up to 6 parts in 10,000 at an inject lon fleld of $0.33 \mathrm{~T}$ at c radius of 1 centimeter. Saturation of the nagnet 1 ron cas induce aextupole fleld errora of 1 to 2 parts in 10,000 at the full fisld of $6.6 \mathrm{I}$. Manufaccuring errors can Induce other aultipole components, both normal and skeu. The SSC coll has three vedien eparating the superconducting cr:l b2ocks on the lnner layet of the coll. These vedges nust be accurately located. If the vedgen have superconductori ateched, one cen correct 11 of the annetic fleld witipoles (both normal and akew) from $\mathrm{N}=1$ (d1pole) to $\mathrm{N}=6$ (12 pole). This peper describes thl sethod of correction as it pertains to the SSC dipole angnet.

\section{Backeround}

The SSC machine required sagnets uhich produce a good quality manetic field. The beaw in the SSG machine, partlcularly at infection, le senaltive to algnetit field errors uhich are las than 1 unlt (one unit Is defined es one part In 10000.) A partial list of the types of field errors which aey be preaent in the SSC magnets Include che folloving:[1]

1) Ertors caused by windint fauls in the agnet cause both notali and akev nultipoles in the f1eld.

2) Erross 1ntrodueed by Iron saturation or the Inverse caused by a designed in error whlch goes to zero an the Iron aturatea. Thla error 1s predoninately a noral aextupole tera in the fleld.

3) Eddy currente in the bore rube, tbe colla, the collers and the Iron vill produce predoaInecely noranl sextupole and decapole terms in the fleld.

4) Magnetizacion of the upereonduceor y111 tenerate noral iextupole, decupole and $\mathrm{K}=7$ in the fietd. If the liluent dianeter and the verage auperconductor critical current are not the same in the top and botton colla of the dipole, skew quadrupole vill be tenerated. [2]

5) Stecring errora alght be corrected with a normal or aluev dipole.

6) Tume errora mithe be carreceed with a nored and or ake quadrupole or eextupole.

Several wethode for correcting the fleld in the SSC agnets hes been proposed. Lipped correctors have been used wich wost acceleratora bullt to date but ehere la. queation so co hou far one cap go with this technique on the SSC. The SSC deatga atudy [3] has proposed continuous correction eagnecs vound on cbe dipole magnet bore tube. These correction colls would provide at lease norzal quadrupole, and nomal sextupsle. The nuber of bore tube correction nagnets is limited by the radtal apace inalde the dipole coll. The bore tube correction negnet also have on effect on the bore tube surface temperature when aynchrotion radiation is present at full energy.[4]. Passive correction of angetization nomal sexiupole decapole and 14 pole has been proposed.[5] This wethod will correct the agnetization field reananbly vell provided there 1: not too wuch rariation in conductor propertien betwcen the top and botton cofla.

\section{Correction with Superconductor in the finnet Wedres}

Once one has denongtrated that there is a need for continuouv correction lons the dipole nagnet bore, correction uaing superconductor located on the angnet wedce ahould be considered. [6] The advantages of using the superconducting coll vedges at correction element are as follow:

1) The vedge wat be cecurately locaced alons w th the coll blocke. As a result, the vedge poition determines the conductor polition vith enouch eccuracy to do a cood job of $10-$ cating the correction vindings.

2) The correction occurs along the fult stralght vection length of the dipole magnet. End effect can be compenseted for by sall changes of current in the vedges. (The dipole wegnet length Ia much shoreer than a betation vare lengeh of the vechine.)

3) The bore tube does not have to be anchined or formed beceube te does noc carry carrection $\operatorname{co11a.}$

4) Tbe bore tube can be ared closer to the superconduct int coll uhich perotes one to increate the bean clearance anewhat.

5) The outaide ourface of the bore tube can be hellu cooled alrettly. Hot apots due to aynchrotron radiacion can be redueed great $2 y$.

6) Wedge correction can be uaed to correct the E1rat six wuitipole terns both normal and akes depending on hou the vedzea are hooked up.

Correction uindins on the vedies do present certain prablen, vhich are:

1) The current leada for the vedge corrector nighe hare currente ate high as $150 \mathrm{~A}$.

2) The vedges wat be extruded tn continuous lempths up to 17 aetera. Thid extrusion aust be accurate and the placeant of the auperconductor on the vedge mut not affect the vedge crosu-aection. 
3) Additionol 1noulation on the vedgen any be required in arder to protect ihe correction circule durins a quench of the dipole eneret.

4) Wedgu corroction vil1 requize from 3 to 12 power uupplies per engnet or enenet set depending on the extent of the vedge correctlon. [7] (Bore tube comenention colle vill require at laset two power supplies.)

5) Viedse correct lon ay regulre a laree nubar of gan cooled lesds. These leads can alsalficancly Incrane the refrlgerat 100 aneded to cool the wehlne.

Hedge correction in an SSC dipole anget in $111 \mathrm{w}$ trated in Figure 1 bich ahove 3 vedge correction windinge on the inalde three vedges of the 2 (1) C348A coll croapuectioe. [8] The largest conductor which cen be attached to wedse 1 is about 0.4 sil 10 dieneter; vedige 2 vill allov a 0.3 a dineter opolicondueter; and wedse 3 w11 al1ow a weh larier euperconductor. The arallable correction is Ilated by the eurrest which can be carried in vedges 1 and 2 .

If one 11mits the paik currime in ench codge to 90 percent of the upperconductor eriticel current at $4.3 \mathrm{~K}$ and $7 \mathrm{I}$, one finde thit vodge $\mathrm{l}$ can carm to to $20 \mathrm{~A}$ and vedie 2 can carry up to $140 \mathrm{~A}$. (This le baed on - copper to muperconductor ratio of 1 and evorconductor apecified $J_{c}=2730 \mathrm{Am}^{-2}$ at $4.2 \mathrm{~K}$ and $\left.5.0 \mathrm{I.}\right)$ Iable 1 how the carlma eorrection avallable for the flrat five norel cerme usins the redte conductors uhowa 10 Figere 1.
Table 1. Hardin Correction at Full Field (6.6 I) for Varlous multipales

Fultipole Gorrection avallable (parta in 10000)

\begin{tabular}{ll}
\hline 1 & \\
2 & \\
3 & 4.2 \\
4 & 2.4 \\
5 & 1.1 \\
\hline
\end{tabular}

wat a radius of 10 (ane Figure 1 )

If the vedget are hooked up In way which produces noral dipole ornetry (the currents in the gecand and third quadrante to -1 tines the eurreme in the firet quadrant and the curzenta in the forth quadrane 1 s the sane as those et corresponding pointa in the firet quadrent), one can produce correction for norral dipole (N-1), dextupole (N-3) and decapole (N-5). Table 2 ahow the velues of verlous norral abcicical witipoled when the corrente are ate to produce a dipale of $0.002 \mathrm{~T}$ (3 vitte of correction at foll fleld, acrtupale of $0.00066 \mathrm{I}$ at a radiue of $10=$ ( 1 gads at full $\mathrm{fleld}$ ), and a decapole of $0.00033 \mathrm{I}$ at a radine of $10 \mathrm{E}$ (0.5 unte at full field). Table 3 bow the values of the byetric wedge currente neaded to prodace the correction tield pattern ahow in rable 2 .

\section{SSC DIPOLE CAOSS-SECTION BNL C3SBA COH}

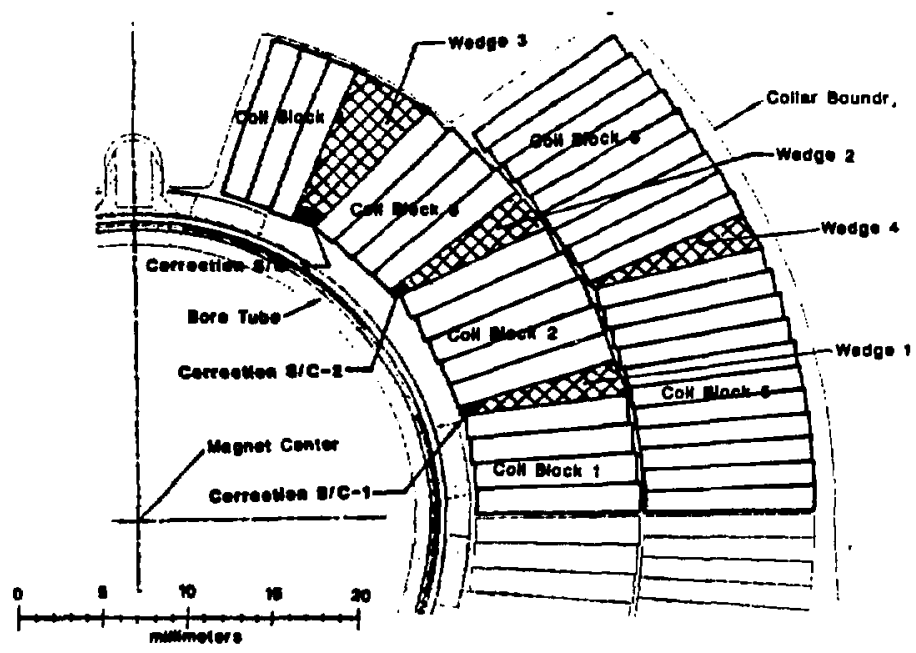


Table 2. The Value of Varlous Symetric Mornal Hultpolea for Variou. Dipole, Sertupole and Decepole Corrections at Full rield

Jultipole
noriber Fuleipole value (T)* $\begin{array}{cc}\text { Dipole } & \text { Sextupole } \\ \text { Correction } & \text { Correction }\end{array}$ 1 unte

Decapole Correcelon 0.6 unites

3 Unit:

$$
\begin{array}{r}
0.00200 \\
0.00000 \\
0.00000 \\
-0.00001 \\
0.00000
\end{array}
$$

0.00000

0.00000

0.00066

0.00000

$-0.00002$

\begin{tabular}{|c|c|c|c|}
\hline $\begin{array}{l}\text { Hedse } \\
\text { ntumber }\end{array}$ & $\begin{array}{l}\text { Hedge Cor } \\
\text { Dipole } \\
\text { Correction } \\
3 \text { Units }\end{array}$ & $\begin{array}{l}\text { Ion Current } \\
\text { Sextupole } \\
\text { Correction } \\
1 \text { Unlt }\end{array}$ & $\begin{array}{l}\text { Decapole } \\
\text { Correction } \\
0.6 \text { Undt }\end{array}$ \\
\hline $\begin{array}{l}1 \\
2 \\
3\end{array}$ & $\begin{array}{r}-32.75 \\
-8.65 \\
-14.97\end{array}$ & $\begin{array}{r}-37.27 \\
21.80 \\
31.10\end{array}$ & $\begin{array}{l}-46.62 \\
111.18 \\
-63.01\end{array}$ \\
\hline
\end{tabular}

7

tac a radius of $10=$

Table 3. The Current on the Hedses in Fisure 1 Needed to Geaerate the tultipoles Shoun in Iable 2.

Method far Bookins up the Hedte Gorrectors ind the teand Refriveracion

Table 2 11 lustrated correetion whe one booke the vedge correction syace up to correct only norand $\pi=1,3$ and 5, The clrcult diegran for hooklns up to correctora to generate the tiela patern show in Table 2 10 ahom in figure 2. This circult is auteable for correctins superconductor agnerization effects, eddy current effect, and 1 ron caturation effect. This c1reult does not correct any skey terma or noriel quedrupole oceupole or Nat. The refrigerathon required to cool the leada for the clreule ahown in Figure 2 is about $1.5 \mathrm{H}$ (11quifaction equitalent) per anenet or troup of 11 ingete. (The extra refriceration solmen to $0.09 \mathrm{~W}$ per meter for one naphet and $0.015 *$ per neter for alx acnet (roups).

The vedge correctlon oyate can be hooked up to correct al! the noral term trom $\pi=1$ throuph Na6. The circult diszra for ualns vedge eorrection to correct only nored hel through 6 is ehour in Figare 3. The refrigeration required to cool tho leada hown in Fleure 3 is about $2.5 \mathrm{~W}$ (11quifaction oquitalent) per Dagnet or broup of a1x aunets. (The extre refriceratlon anoumt: to $0.15 \mathrm{~W}$ per nater tor one menet and $0.025 W$ per aeter for atr wenet eroups.)

The correction elreule thom in Fisure 3 ull correce nose of the cequired cemb. The wor troublesoese cere not corrected to che skm quedrupole which is senerated by unetric menetization of ehe ovperconductor on the tap and botton colle of the dipole.

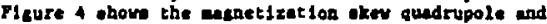
noriel aeztupole ararated by an SSC dipole with I11eneat dieneter in the upper cotl of 5.25 alcrons and

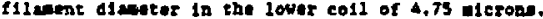
$A$ noral sertupole of 6.7 unt occurs at Infection. The ten parcent top-botion rarietion of fllament diencer yill cenerace f1rst, to firat ordar, Juet over 1 ale of akey quedrupole at Infection, Dat ear reduce this term trenty by operconduetor qualIty control and by shuffilin the euperconductors in the cables ued to bullo the dipole.[9]

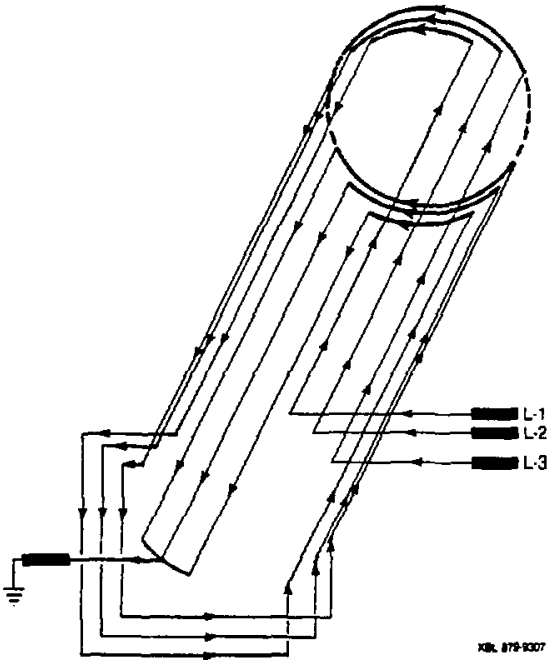

and and

Fi gure 3.

CIRCUT OAGRAM FON WEOGE COARECTOAS CORFECTS IN, ZN, 3N, AN, 5N ANO GN

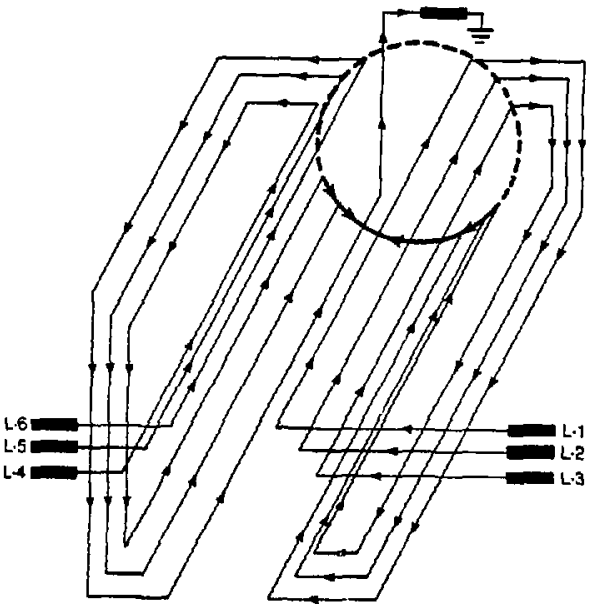


RATHO OF MAGNETIZATION FIELD TO TRANSPOAT CUASENT FIELD WITH A TEN PEACENT TOP BOTTOM ASYMMETAY OF FILAMENT DIAMETER

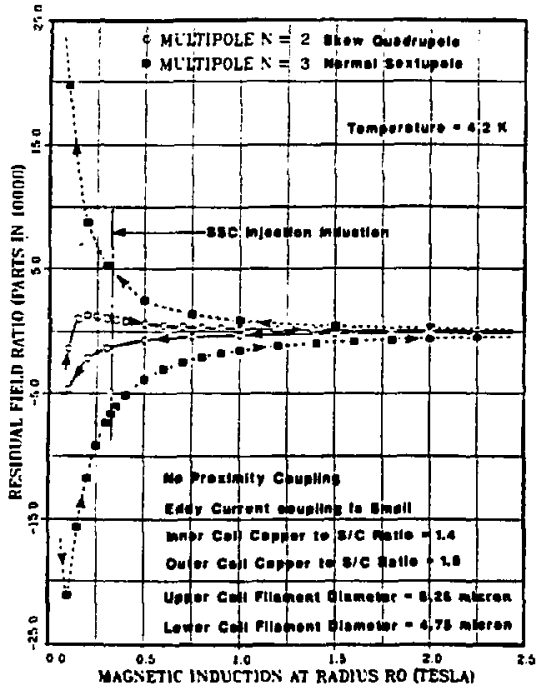

Figure 5.

CIRCUTT DIAGAAM FOA WEDCE CONRECTOAS COARECTS IN, ZN, $3 N, 4 N$, $5 N$ AND EN COPAECTS IS, 2S, 3S, 4S, 5S, AND ES

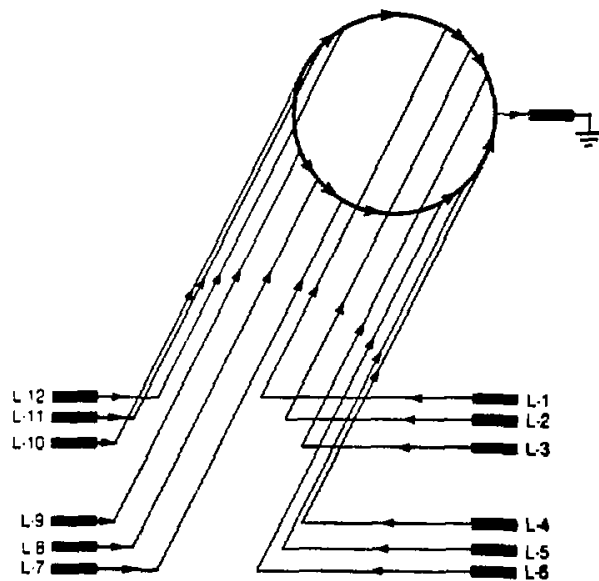

Wedse correction pergite one to correct the flrst atx teral of both the norval and wkes fielda ahould that becone necesany. The ctrcutt diaran for the correction of all of terma is thown in Ficure 5. There are thirteen leads for each aet of correction calle. These lesde $y 131$ requlre ebout $4.5 \mathrm{H}$ of r.sfriceration (equiralent 11quifaction) per set. ("Thlo inounta to add reficistation of $0.045 \mathrm{~W}$ per meter for a set of correction vedres for alx maneta in aer(;

\section{Concludine Coments}

Superconductor mowted on the S5C dipole magnet vedees can be voed to correct the masnetle field in the SSC accelerator. Hedge correction can correct more mitipoles than ither luped correction colla or continuou bore tube correction colle, wheh correct tro or three teras. The thrae Inner vedtes can be uned to correct 11 terwe normel and akew fron $n=1$ (dipole) to $\pi=6$. The price one paya le additional compllcstion of the dipole manats and additional hellu refrigeration needed to conl the extra anet leada. (Thls refrigeration ean be reduced by puteins the vadges in aix dipole nagnete in serien.) wedge correction will result in the cilmination of continuoun bore tube correction solls and it could renult in almpileation of tae SSC lumed correction manet oraten.

\section{Ackovistaente}

The author chanks J. H. Peterwon of the 5SC Control Desten Group and C. Z, Taylor of the Lavrence Berkeley Laboratory far their concents. Thlo vork vit performed under the Awoplees of che office of Basfe Inergy Sclences of the U,S. Deperteent of Ineray under Contract Ro. DE-ACO3-765roooge.

\section{Pefierencet}

[1) Enotic Frror in ehe Ssf, report of the Magnet errora work1ne rroup, SSC-7, Apr11 1985.

[2] H. A. Green "ssc soperconductire Dipole Hener, Aberration dun to Aaymetries in Current, Filaarte ind Cricical Current", LBL Enclneerins Note H6670, S5C-11-377, Auguat 1987.

(3) Supereonduestne super coll1der Conceptunt peish Report SSC-Sz-2020, Farch 1986.

[4] J. D. Jacknon, "Conduct on of Beat of Synchrotron andiation through the Wrapped Bear Tube Wall". 3sc-1k-235, Septenber 1986.

[5] M. A. Green, "Conerol of the Field due to Superconductor Hignetineton in the SSC Hagnete", IEEE Tranactions on Fagnetica, HAG-23, Mo. 2, p. SO6, Fareh 1987.

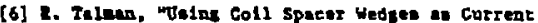
Carryins Fleld Triming Blesenten, SSC-R-208, July 25. 1946.

[7] H. A. Green -3sC-Dipole Mornet, Uains the Wedse: to Carry Fielo Ir1e Coli" ", LaL W6641 A, ssc-n-319, Apri1 1967.

(a) Drookharen Nationel Laboratory Dravins $22.273 .01-54$, March 18. 1986.

[9] H. A. Green, MGsss Machine Denien Conttee Reporte", Gisss-in-2l on Conductor Shurridnt, p. 54-60, Kerpforechuarezentro Rarlaruhe Report RT 1764, Jume 1973. 